\title{
CLASSIFICATION OF UZBEK AND ENGLISH INTERJECTIONS ACCORDING TO THE AGE
}

\author{
Karimova Z. \\ Lecturer, TSAU,
}

Article DOI: https://doi.org/10.36713/epra4259

\begin{abstract}
ANNOTATION
The research paper aimed to classify Uzbek and English interjections according to the age. The famous Uzbek and English novels were served as the data of the research. In our study, we analyzed the position and meaning of Uzbek interjections and compared with English interjections. The research results showed that interjections form a separate class of words according to the age.
\end{abstract}

KEY WORDS: Uzbek language, English Language, interjections, exclamations, age differences.

\section{DISCUSSION}

Success in intercultural communication requires more than just acquiring a foreign language and its usage. Successful communication also depends on intercultural communication skills of communicants'. In addition, a poor understanding the culture of the comparable language can also lead to failure in comparing language elements.

Communication is the product of human thinking. Different speech acts are created according to their goals, depending on the speaker's age, gender, and cultural background. The speech act is a speechdirected speech action, normally accepted by society and acted in accordance with the rules of speech behaviour. [1]

The difference in the age of communicants is reflected in their speech as well. This distinction depends on the national mentality of every nation. Mainly, the use of request forms by age is unique to Uzbeks' communication culture. [2] It shows that the speech of a person also informs about his age.

Interjections are the most common unit of everyday speech of all nations, and is the unit used in infants' speeches to older ones. The first word of a baby is "inga", which means that they were born. Then, in this voice, we realize that they need something, for example, to let them know that they are hungry, sleepy, in pain or have other wishes. As they grow older and become more fluent, their vocabulary enlarges.

This case is the same in all nations. They only use words to satisfy their needs, for example in Uzbek "nanna - bread, umma - water, qaqqa - candy, lalla - milk, and so on. From both perspectives, parents or educators teach children words such as Ассалому алайкум - Good morning/afternoon/evening, Рахмаm - Thank you/thanks, Кечuрасиз - Excuse me/Sorry, Илтимос - Please. These words will continue to develop in their speech. Imitation is also characteristic of children.

Emotive words are common in children's speech as well. This indicates that they are emotionally involved.

Producing long vowels in words and doubling consonants is also a phonetic phenomenon observed in children's speech. Such pronunciation enhances the effectiveness of speech and exaggerates the meaning of the word: Xoo!, Вyŭŭ!, Bo-oŭ!, Мазза! (enjoy).

In the Uzbek language, the word "aŭ", and in English "aw" and "ouch" are more common in the speech of children, which mean mainly pain.

When eating or tasting a delicious meal, the Uzbeks pronounce in the form of ox-ox-ox or ax and in English yum, yummy. These words are used by both adults and children alike.

The word вax is interpreted in the Uzbek explanatory dictionary as sudden, silent word to scare someone. I was scared when he stopped behind me and said "вах". [3] In our opinion, this interjection was not fully explained in the Uzbek linguistic thesauruses, that is, no other definitions were given. In the children's speech, the word "ваx" (wah) is used in the above sense to scare someone. We have also found this word in the form of бўх. In this sense, it can also be used in joking among middle-aged 
people. In belles-lettres style, we can see broader meanings. For example:

1. Kesakpolvon saw Oysanam when she was young girl. Again, he saw the girl when Ilyasov got married to her; he saw the woman and he hardly kept himself saying, "Bax!" (Wow!). He felt sorrow for loosing her and thought: "How could I let the bird in my hand fly to him". Then he calmed himself by remembering the saying: "If you want to sell a carpet, sell it to your neighbour and you may sit on the side whenever you want." (Shaytanat, Book 4, The Satans' place). As we have seen in this context, "Bax!" expressed the regret.

2. Mushtariy paused for a while. As her sister says, she tried to hear the silence and whisper of the moon. Then she raised her head and stared at Cholponoy "Allah, Allah, how the darkness of estrange is so great and makes the hearts and souls vagabondize". When Cholponoy heard her sister's sad words, she smiled and stroke her eyebrows, cheeks then uttered "Bax, ваx! The meeting of sweethearts like the brightness of the dawn is delightful and inspiring.... (Shaytanat (The Satans' place), Book 4,). In this example, the repetition of words describe delight and happiness. The above meanings are mostly found in older people's speech. "Booh!" means scare in English. However, "Booh!" does not mean joy or happiness.

Some middle-aged women and men turn to their spouses with excuses such as хай, хей, хў̆ э (hy, hey, huh, o, e) and oxaŭ in some areas. In the past, calling the husband or wife with the first name was shame, since it is still tradition in some territories of our country.

Even though Makhdum had been waiting for this news for a long time, he got excited. He asked the young man to wait for a while, who had come to inform him about good news and wanting to get some gift. Makhdum ordered two boys to sweep up the living room, and let the rest of children go home. He hurried to home and called Mother Nigor amongst the girls:

"Hey," he said, "Anvar send a man with message. Open your chest!"

Mother Nigor did not understand this hasty words.

"Why did Anvar send the man and why should I open the chest?"

"Oh, you are fool," he said cheerfully, "Anvar had been honoured with high position in the khanate and a guy came to get a gift for the news; I want you to open the chest and get something suitable for the gift, be quick! (A. Kadiri, Scorpio in the Altar. The Novel) But the English address directly by their names or they often use the word dear.

The word "Ë пирuм" is often used in the speech of elderly people. They use the word when urging themselves to move, get up, sit or raise something. The meaning of the word пирим is defined as surprise; worship the saints of Islamic world in the Uzbek explanatory dictionary.

"There was a whisper among those who did not know what was going on." They say the heroes who arrived yesterday had already tired. But, the hero from Zirillama turned to be a nightingale took after crow. The channel building is about to end. After all, can we hoe just saying yo pirim ("ë пирим"). (S.Ahmad, The Horizon.)

The "bachkanadoz" usually started his work at dawn and did not go anywhere till noon, but today he left the store before noon. He walked along the edge of a street filled with dirty snow and muddy water, sticking on the walls and keeping his big stick at every step he uttered «ё пирим!» and hardly went out into the square. (Oybek, Memorial Blood.) There are also signs of surprise and admiration, and the change in tone depends on the situation.

In the following context, the word ë пирим is used repeatedly, and increases the meaning of amazement. We can find this expression more often in women's speech:

"I don't want to marry him, he is bald," she said.

- Ё, пирим-ей, ё пирим-ей! (Yo pirimey, уо pirimey!) Who knows what may happen! Why do you worry about his baldness? Is his baldness the only problem? You think that if a man is not bald, he is intelligent; you are wrong. Some man are gifted with thick hair, some are not. That's what the creator did! (The Novel, The Night When A Horse Neighed) In addition to the word Yo pirimey, the words "Oh Allah, O Lord" can be used either:

He liked to get up early in the morning and after the ablution to wander in and out of the courtyard, picking the grass fallen from the horse things in the dark, and look at everything, even in the dark. When he got to the stabling, Shokasim shouted:

"Oh Landlord, you woke up earlier today?" But, the Landlord Parpikhodja instead of answering him said "Yo Allah" and began to look for fodder for the horses. (Oybek, Memorial Blood)

It should be noted that religion-related sayings grow with age. Such speech is not uncommon in children. As person grows older or becomes more aware of the religious sciences, they will continue to grow in speech. We know that there are many words and phrases related to the religion: Bismillah, Subhan'allah, Allahu Akbar, Insha'Allah, the Most Merciful, Allah, the Most High, if Allah Wish, the Most Gracious. The first words we teach a child is Bismillah and Amen. In Muslim families, a child is taught to say Bismillah before eating and Amen after eating.

Most Uzbek mothers say Bismillah before breast-feeding their babies. This is a peculiarity of the Muslim people as well as the Uzbeks. At the same time, these words penetrate into the child's mind, and as they begin to speak, these words slowly begin to 
appear in the child's lexicon. These words are constantly heard in people's speech as they become older. The speech of grandparents is unique in the Uzbek culture of communication. They follow speech etiquette. It is also noteworthy that there is always a lot of advice in their speech:

- Amen! May Allah be with you and returns you home safe. Have fun, but don't go down Hodjaqochqor Fall if water level is higher. Okay, Jurajon? Sister, take care of him, please. I know the waterfall; it hits the shoulders like a rock. So ... By the way, do your wives also go? Do not stay up late, the mountain is cold, sister, remind them about it, they may forget. Okay. I will prepare pilaf for dinner. Is your car "Willis?" (Sh. Kholmirzaev, Selections, Volume 1)

We know that these two nations under study belong to different religions. The relation of both nations to their own religion is reflected in the works of great writers and in the conversations taking place in these works. English (especially in the UK) avoid religious words as much as possible. Religious words are mostly found in the discourse of the clergy. Consequently, the above linguistic units are expressed mainly in the dialogic rhetoric of the Uzbek people: Astaghfirullah! The only Allah knows. It is not the job of ordinary men to teach how to trial. Only Allah decides who should be judged, what should be examined: his faith or belief, and Allah is the Greatest ... (Tahir Malik, Hunting. Story 4-b)

Finally, Rukhsat opa was asked to say Fatiha, "May Allah be with you!"

- If I am not mistaken, are you Mirza Anwar's teacher?"

- Yes ...

- Is everything good in your home?

- Alhamdulillah.

A young man about forty, showed an unexpected politeness to Makhdum. He was tall, with long black beard, dark-skinned man and with blue turban lowered to the eyebrows. (A.Kadiri, Scorpio in the Altar)

The concept of God is the same for all nations. However, in Uzbek, it is called Khudo, and in English, it is called God. The request interjections have also unique peculiarities. In the Uzbek language: Оллох! Оллохим-ей! $\ddot{E}$ Худо! Ё Оллох! $\ddot{E}$ парвардигор! Э парвардигорим! Э худойим! Э Оллохим! Вой худо! Вой худойим! Ё раб! Ё тангрим! In English: God! My God! Oh God! Oh my God! Lord! My Lord! Good Lord! We encounter these units, from middle-aged to elderly people's speech:

Both Khudoydod and Khudoykhan couldn't sleep that night. They kept their eyes on the phone. Finally, Khudoydod was about to burst with waiting and dialled the numbers.
- Where are you, silly one? Why don't you call? He shouted angrily.

- Things look bad, brother!

-Just tell me, (Хўய-хy̆m) what's wrong!

- Amonzade was killed.

- ... Oh my God! God bless him.

- Well, brother, now listen to me. He was shot when he tried to escape. Nurmat aka and the owner of the house were imprisoned. (Nabijon Hoshimov, Scorpios' Pathway)

"Call everybody to the wedding to Uncle Tolqin's home, Shout out: All are invited to Tolqin Tank's home, for wedding, and let your voice be heard in Vakhshivor," he said with a sigh. - Yes, say so. My children! Today is the day when Tolqin Tank revived. Today, Tolqin Tank will hear your voice. Today, Tolqin Tank sees you all and knows. - Then he said to himself, "Эх, худойuм-a, (Oh, my God), what is fate?" He added. (Qochqor Norkobil, Mystery under the sky)

$\ddot{E}$, Paб! (O God!) It was just what his father, Emir Sabuktegin, said! Indeed, it is the good fortune! Good foil! (O.Yakubov, The Old World) if to himself,

Jonathan kept looking after him, and said, as

'I believe it is the Count, but he has grown young. My God, if this be so! Oh, my God! My God! If only I knew! If only I knew!' He was distressing himself so much that I feared to keep his mind on the subject by asking him any questions, so I remained silent. (Bram Stoker, Dracula.p: 310. http://www.planetpdf.com/.)

"Of course not," said Lady Tamplin. "She has been a companion, I tell you. Companions don't play tennis-or golf. They might possibly play golf croquet, but I have always understood that they wind wool and wash dogs most of the day."

"O God!" said Mr. Evans; "do they really?"

Lenox drifted upstairs again to Katherine's room. (Agatha Christie, The Mystery of the Blue Train)

'Good Lord! Sir William, how can you tell such a story? Do not you know that Mr. Collins wants to marry Lizzy?' (Jane Austen, Pride and Prejudice/ p: 194. http://www.planetpdf.com)

Saying duas or praise to interlocutor is often seen in speech of older Uzbek mothers. Praying in the Uzbek language are too long. In English, they are characterized by short form. [4] The elderly mothers often raise their hands to pray, and also our fathers and grandfathers. Of course, in the process of praying, such prays and exclamations as илохим, илохи, илойим, илоё, илохо омин, омин, аллоху акбар (amen, amen, Allahu akbar) are also reflected in the speech. In Uzbek:

... Finally, the old man's blessing, that is:

- Amen, may all your wishes come true. May our country be peaceful and prosperous. And as we have said, may we also enjoy in the independent country. (Sh.Kolmirzaev, Selection 2 Stories. P-347. 2005)

Then Bob proposed: 


\section{'A Merry Christmas to us all, my dears. God bless} us.'

Which all the family re-echoed.

'God bless us every one.' said Tiny Tim, the last of all. (Ch. Dickens, A/Christmas Carol. P. 80 http://www.planetpdf.com)

Rahmatullah stopped for a moment. It was not a simple deer screaming what he heard; it was pure, ringing sound “Allahu akbar!"... (Tohir Malik, Hunting. Story, p. 7)

In the above we mentioned that interjection Byŭ is used mainly in women and children's speech. The feeling of excitement in children is stronger than in adults. One of the main characters in U.Khashimov's novel "Between Two Doors" Muzaffar's mother from "Kokand" gives him a new skullcap. His schoolmate Abduvali saw this. Through Abduvali, the author skillfully demonstrated how вуй sounds in child's speech.

Abduvali saw me when I take my new skullcap out of my pocket and put it in the briefcase.

- Вуй! (Wow!) Where did you get it?

- I found it!

- How's that? Can I have a look at it?

- Shomurodov! The teacher shouted. "There was quite silence when you hadn't been in class." You're so noisy! stomach.

Again, I'm guilty! I kicked Abduvali into his

Shomurodov!.... the poem describes how Uzbek people cared about thousands of children, orphaned by the war......

I carefully put my skullcap into my briefcase.

What's in your another pocket?

He is so bad, yellow cat! The kicking did not work on him. Alas! Let's take a look! I myself will buy bike. From Dynamo Store! I saw it in the summer when we were in town with my dad! That's right! I do not need pants. There's another one in the house! I'd rather take a bike.

I slowly took money out of my pocket.

Byŭ! (Wow!) - Abduvali's eyes widened. "Where did you get it?"

"It is not your business?"

- Shomurodov! I'm in class. (U. Hashimov, Between Two Doors, P. 396-397. 2015)

The black bump clods of soil were like the heads with black caps, and the children turned up the earth with ploughs with pleasure.

- Вуй! (Wow) What a big thing!

"That's like the soldier of Sepkilshah."

- Well, let's kick it. Look!

- Hayuv-v !!! (A.Abidjan, Battle of Meshpolvon)

The interjection Byŭ (wuy) is also used in the form of вoŭ-вyŭ.

Urra / hurrah is commonly used in both languages, not only in the adult language, but also in children's speech:
"I am preparing meal til Salim will come out," my mother whispered, and there was a loud shout from the gate.

- Urra! My junior dad has come!

Two sons of my brother rushed into the yard. They ran like bullets and clung to him. They seemed to play football somewhere, because they were extremely sweated. (U. Hashimov, The Frightening Dreams. P. 148. Tashkent 2002)

At that time, the children shouted: "Urra! The camel has came back!" Parizoda quickly looked up at the top of the cliff and exclaimed:

"Mama, my sister caught her camel!" She is coming with it. (N. Khoshimov, The woman in man's wear. 42. library.ziyonet.uz)

"Here's Martha, mother!" said a girl, appearing as she spoke.

"Here's Martha, mother!" cried the two young Cratchits. "Hurrah! There's such a goose, Martha!'(Ch.Dickens, A Chrismas Carol. p.75)

Then he took the skulls and put them in the lathe and turned them till they were round. 'There, now they will roll better!' said he. 'Hurrah! Now we'll have fun!' He played with them and lost some of his money, but when it struck twelve, everything vanished from his sight. (The Brothers Grimm, Grimm's Fairy Tales. P.401http://www.planetpdf.com)

It is also worth noting that many people do not control their speech, are lazy in search of words, do not know the Uzbek forms of Russian terms, and in some cases try to demonstrate their proficiency in Russian: «Эрталаб звонить қилдим» (I called you in the morning), «Эртага экзамен сдавать қиламан» (Tomorrow I am taking exam), «Ўџa приёмнийда ишлаётган йигит жуда симпатичний экан», ("The guy who works in the reception is very attractive". T.Qudratov, The Fundamentals of Speech Etiquette. The manual for primary education and methodology P-51. 1993) This can also be observed in exclamations. Маладес, браво, ладна, привет, канешна (Malades, bravo, ladna, privet, kaneshna):

Khalik rejoiced, went back, crossed the pipe, and proceeded down the ravine. He continued walking on the scattered straw and the alfalfa flowers......

- Yes, nephew, malades, nephew! Sit here! - said the uncle from the city. Khalik blushed, climbed to the seat, and walked with his knees, raising his feet to avoid touching the carpet. The uncle kissed his head and sweaty forehead.

"Look at me, you have already grown-up" said he. "Yes, yes ... Oops (Балли, балли... Ў) your beard has been grown." Yes, malades! Would you still imitate or give it up? You should not give up it is a unique profession. (Sh.Kolmirzaev, Selections, Volume 1, page 110, www.ziyouz.com library) The deputy director sighed deeply: 
"I thought of freedom," he said. - Is it true Shotura aka?

"Kaneshna, that's right," said Shotura.

Mansur suddenly looked at him. (Sh.Kolmirzaev, Selections, Volume 2, Stories. 307 p. 2005)

Squint-eyed liked the complement and laughed. "You heard, wow (вy̆), it is cool!" He said to his companions. "Oh, get out, don't cheat," said the boy sitting in the right. "Stop, don't," said Shamil Squint-eyed. If you are clever boy, you will become great man. What's your name? - Hosil. - Great! Nice name! You will become rich person, not simply (прўста) Hosil. You will become very handsome rich man! Shamil hit him on the shoulder. He opened the cigarette and put one on his lips and then held it to his companions. (T.Malik, Shaytanat. 8 pp. Library.ziyonet.uz)

Nowadays the words in the youth language are English ok, wow.

The only way to get rid of such barbarisms is to respect one's mother tongue. From an early age, we should teach children to speak pure Uzbek language, in any case. It is the duty of every parent and educator to teach children despite who they are talking to (whether they are with their friends or with others), not to use the words "inappropriate" come from outside.

It is also worth noting that there are other interjections of encouragement that have already been included in everyday speech of young people. One such interjection is вачаaч (wachaaach). Though this word is not included in the literary works, it is often found in speech of boys aged 15-25. They use this speech unit when they hear something new, chuckle at their peers, or laugh at them. - My son has excelled in all subjects. "Wachaaach!" And I am proud of my nephew!

We have concluded that the interjections of Uzbek make up smaller group in comparison with English according to the age. As we have seen, various interjections can be used to express certain emotions or attitudes according to the age of speakers.

\section{REFERENCES}

1. Crystal. D, A Dictionary of Linguistics and Phonetics, Basil Blackwell, Oxford. 1985.

2. Guide to Grammar and Writing. What is an interjection?

http://www.uottawa.ca/academic/arts/writcent/hy pergrammar/interjct.html

3. Madvaliev A, Explanatory dictionary of the Uzbek language. P.680. Volume 1. 2006.

4. Qurbonova $M$, The pragmalinguistic analysis of speech acts charachteristic to children. Foreign Philology Journal. №4, 2016.

5. Yuldasheva Kh.Q, Sociolinguistic study of the Uzbek historical novels. Contents of dissertation abstract of doctor of philosophy (PhD) on philological sciences. 2017.

6. Samigova Kh. B, Contrastive analysis of the rhetoric aspect of the English and Uzbek speech culture. Инглиз ва ўзбек нутқ маданияти риторик аспектининг човиштирма тадқики, Contents of dissertation abstract of doctor of philosophy (PhD) on philological sciences. 2009.

7. Yule, G. Pragmatics. Oxford: Oxford University Press. 2006. 